\title{
Foreign Direct Investment (FDI) Inflows into Ghana: Should the Focus Be on Infrastructure or Natural Resources? Short- Run and Long -Run Analyses
}

\author{
Prince Acheampong ${ }^{1} \&$ Victor Osei ${ }^{2}$ \\ ${ }^{1}$ Department of Accountancy, Koforidua Polytechnic, P.O.Box KF 981, Koforidua, Ghana \\ ${ }^{2}$ Candidate for Msc. Economic and Quantitative Finance, Perking University HSBC, Peking University, China \\ Correspondence: Prince Acheampong, Department of Accountancy, Koforidua Polytechnic, P.O.Box KF 981, \\ Koforidua, Ghana. E-mail: owoahene6@yahoo.com
}

Received: December 5, 2013

Accepted: December 27, 2013

Online Published: January 10, 2014

doi:10.5430/ijfr.v5n1p42

URL: http://dx.doi.org/10.5430/ijfr.v5n1p42

\begin{abstract}
This paper conducts a time series analysis of annual data set from 1980-2010, to study the potential determinants of FDI inflows to Ghana. The paper used modern econometric methodology which includes unit root testing, and co-integration analysis. Both the long-run and short run determinants of FDI were analysed using the Vector Error Correction Model (VECM). The VECM also enabled the researchers predict the speedy with which the short- run and long- run disequilibrium is corrected. The robustness of the estimated coefficients was investigated and found to be robust. The research reveals that infrastructural development and political stability have long-run positive and significant impact on the level of FDI inflows in Ghana. The study further established FDI targeting Ghana to be predominantly resource seeking for now. The short-run estimate for natural resources is positive and significant. However, Ghana cannot continue to rely on its natural resources to attract FDI as the long-run relationship is negative. Factors associated with market and efficiency seeking FDI such as market size, and value of the cedi were either found to be insignificant or unstable coefficients on inflows. Political instability is found to significantly deter inflows implying that strengthening of democratic institutions can bring in economic dividends by serving as a driver of FDI. The state of infrastructure is found to be below the required level necessary and sufficient to serve as a driver of inflows hence the negative short term effect. The policy implication of this finding is that for Ghana to fully realize its potential as far as foreign direct investment inflows is concerned it needs to embark on massive investments in infrastructure.
\end{abstract}

Keywords: foreign direct investment, political instability, real exchange rate, infrastructure and gross domestic product

\section{Introduction}

There is consensus and acceptance among academics and policy makers concerning the significant correlation between economic growth, private savings and investment. In the light of this, it is not all too surprising that high performing Asian economies and other emerging economies have high levels of private savings relative to GDP (for example much of the 1990's saw china's savings rate averaging $40 \%$ of gross domestic product and has in recent years grown to about 50\% of GDP). Sub-Saharan Africa in general and Ghana in particular, however, has lower level of private savings in comparison to other parts of the world. In comparison to $23 \%$ of gross domestic savings to GDP for South East Asia, Africa had an estimated 8\% of gross domestic savings to GDP in the 1980's. Aryeety \&Urdry (2000) report a general level of decline in domestic savings in the decade that follow the 1980's. A more disturbing dimension to this tragic episode has been the unstable nature of savings in Sub-Saharan Africa. Elbadawi \& Mwega, (2000) observed that the coefficient of variation of savings estimated for the region is found to be three times that of the Asian economies

In order to satisfy the huge investment needs of the continent, governments have had to rely on foreign capital flow. In the 1990's governments in the developing world prioritize alternative forms of foreign capital inflows official development assistance, remittances from citizens' abroad, and private transfer over and above foreign direct investment. Much prominence was not given to foreign direct investment until the mid-90. This followed after several years of ODA had failed to produce and sustain economic growth the continent so much desire. Also the tendency to build up debt through foreign lending had deterred various countries from embarking on this alternative 
of foreign lending (Obwona \& Egesa, 2005). This precipitated a rethinking which resulted in a paradigm shift from ODA to foreign direct investments (FDI).

With almost universal acceptance, FDI has now been identified as a crucial element for sustained growth in developing countries. The premise for this assertion lies in the fact that foreign direct investors turn to have long term outlook in a host economy. This feature of FDI makes it less volatile in times of financial crisis and a very reliable source of investments.

The inflows of FDI benefits host economy in many ways. One of such benefits is the potential to bridge the gap between low levels of domestic savings and investment. Secondly, relative to other forms of foreign capital inflows, FDI is more likely to be directed toward productive activities. This makes FDI a credible source of stimulant for economic growth in any economy. The potential access and transfer of modern technology has often been cited as a major benefit that accrues to host economy. Multinational corporations which are the major sources of FDI have access to superior technology vis-à-vis domestic firms. FDI facilitates technological spillovers when MNCs have to upgrade domestic firms in order to satisfy the high standards of international market (Dupasquier \& Osakwe, 2005). In addition benefits, FDI turns to be less volatile and as a result is seen as a very reliable source of capital to the host country. The stable nature of FDI is due to the long term view usually employed by the foreign direct investor. Another important factor that contributes to the stability of FDI is the fact that it is typically invested in physical assets. These factors make retreating FDI particularly difficult. The presence of MNCs increases the degree of efficiency present in host market. This is because multinational corporations bring about high levels of competition in the host market. Domestic firms in their bid to survive, strive to improve upon current levels of efficiency. Another significant benefit of FDI inflows is the improvement in human capital of the host country. In order for transnational enterprises to remain competitive in market place they have to upgrade the skill levels of their employees through training. The human capital base of domestic firms is also enhanced through their association with Multinational corporations (e.g. vertical linkages). FDI also contribute significantly to gross capital formation of the recipient economy. This positive affects the balance sheet of host country without imposing the burden of debt. Finally, FDI inflows help in integrating host country economy into regional or global markets especially if it is export oriented (Kobrin, 2005).

The immense FDI liberalization policies and massive improvement in the business environment have not had a commensurate effect on FDI inflow. FDI flows to Ghana can at best be described as erratic and at worst insignificant to engender and sustain economic growth. Between 1993 and 2005, annual FDI inflows fluctuated between US \$50 million and US \$250 million. In 2006, FDI rose to almost US \$450 million (Aryteey, et. al, 2008). Relative to countries in the sub-region UNCTAD (2007) reports that Ghana's performance is far less impressive. The level of inflows becomes more worrying when one considers the fact that neighboring countries have been economical with reforms, less stable politically and less endowed in natural resource. Indications from the 2014 proposed budget as presented by the finance minister, Seth Terkpe on the floor of parliament point to the fact that there has been some improvement in FDI inflow over the past few years to the extent that Ghana is now among the three top Countries in west Africa enjoying large inflows of FDI. So what has changed? Why the new focus on Ghana? Are FDI flows into Ghana Infrastructure driven or Natural Resources driven? This paper explores major determinants, of foreign direct investments inflows in Ghana. The paper also suggests appropriate ways of attracting and enhancing FDI in Ghana.

\section{Empirical Methodology}

\subsection{Data Description and Sources}

The data used in this study is a yearly observation covering the period $1980-2010$. The data was retrieved from the World Bank development indicators CD ROM as well as from Ghana investment promotion council (GIPC). The choice for independent variables as well as the period of the covered by this paper was dictated by literature and availability of consistent data.

\subsection{Definition of Variables and a Prior Assumption}

\section{Dependent Variable}

FDI/GDP (FDI): Foreign direct investment are the net inflows of investment to acquire a lasting management interest (10 percent or more of voting stock) in an enterprise operating in an economy other than that of the investor. It is the sum of equity capital, reinvestment of earnings, other long-term capital, and short-term capital as shown in the balance of payments. This series shows net inflows (new investment inflows less disinvestment) in the reporting economy from foreign investors, and is divided by GDP.

\section{Independent Variables}

Market Size (MSize): The importance of market size for market seeking inflows is significant. The motive is to produce and sell in the host economy. The hypothesize runs; large market will attract FDI inflows. The proxy used to 
measure the size of market is the Gross domestic product (Asiedu, 2006 and Vijayakuma et. al, 2010). The study expects a positive coefficient for this variable $\left(\beta_{1}>0\right)$.

Exchange Rate (REEX: the strength of a currency is an important factor in attracting FDI. It is hypothesized that a strong currency will enhance the flow of FDI as investors' associate strong currency with less exchange rate risk (Chakrabarti, 2000).The standard in literature is to use real and effective exchange rate to measure the strength of currency. Real effective exchange is the currency index of weighted average of a country's currency selective to basket of major currencies adjusted for the effect of Inflation and is a proxy measure of strength of a currency (Vijayakumar et. al., 2010).

\section{Political instability (Pol)}

Volatile political climate has often been ascribed as one of the reasons for lack of investments on the continent. The hypothesis runs that political instability act as a deterrent to private investment. The political instability is indexed by finding the average rating of international country risk guide for military presence in politics, internal strife and ethnic conflict.

Natural Resources (Nat): FDI inflows into natural resources in Africa have been particularly strong; this has seen inflows becoming concentrated in extractive industries. The hypothesis runs that natural resources endowment will enhance the flow of FDI. The share of fuels and minerals in total exports is used in literature to serve as a proxy for natural resource (Asiedu, 2002). The researchers expect a significantly positive relationship between this independent variable and the dependent variable.

Infrastructure(Infra): Appropriate and quality infrastructure reduces the cost of conducting business and as a consequence increase returns on investments. The standard in literature is to use number of telephone lines per 1000 people as a proxy for infrastructure.

\subsection{Econometric Models Specifications}

After reviewing literature, empirical considerations and availability of data the basic regression model employed is presented below:

$$
\operatorname{In} \frac{F D I}{G D P}(F D I)=\alpha+\beta_{1} \operatorname{InMSIZE}+\beta_{2} \operatorname{InREEX}++\beta_{3} \operatorname{InPOL}+\beta_{4} \operatorname{InNAT}+\beta_{5} \operatorname{InINFRA}+\varepsilon
$$

\section{Where:}

FDI

MSIZE

REEX

POL

NAT

INFRA

$\varepsilon$

The notation In is a denotation of natural logarithm. The basis for performing log transformation is to reduce the problem of heteroskedasticity because log stabilizes the variance of a series by compressing the scale in which the variables are measured (Frimpong \& Marbuah, 2010).

\subsection{Empirical Econometric Methodology: Unit Root Testing, Co-integration and VECM}

\section{Unit Root Test Procedure}

In testing for the stationarity properties of the time series data set, we conduct a unit root testing using the Augmented Dickey-fuller (ADF) approach. The tests for stationarity and the estimation procedure are appropriate for analyzing the determinants of FDI inflows. Many test procedures are available for testing for a unit root in a time series data. The researchers however, used the most popular Augmented Dickey-Fuller (ADF) test. We confirm the robustness of the ADF results with the Philip-Perron unit root test. This we do to avoid spurious regressions which results when the variables in the ordinary regressions are non-stationary.

\section{Co-integration Test Procedure}

We used Johansen \& Juselius (1990) maximum likelihood (ML) procedure to test for the number of Co-integrating vectors which also allows inferences on parameter restrictions. The Johansen Co-integration equation is as follows: 


$$
\Delta X_{T}=\sum_{i=1}^{q-1} \Pi_{i} \Delta X_{t-i}+\Pi_{q} \Delta X_{t-q}+\mu+v_{t}
$$

Where: $X_{1}$ is an $n \times 1$ vector of variables, $\Pi_{q}$ is an $n \times n$ matrix of rank $r \leq n, \mu$ is an $n \times 1$ vector of constant term and $v$ is an $\mathrm{n} x$ 1vector residuals.

The hypothesis is $\mathrm{H}_{0}=\Pi_{\mathrm{q}}=\alpha \beta$, where $\alpha$ and $\beta^{!}$are $\mathrm{n} \times \mathrm{r}$ loading matrices and Eigen vectors. This procedure is done to test the number of $\mathrm{r}$ co-integrating vectors $\beta_{1}, \beta_{2} \ldots \ldots \beta_{\mathrm{r}}$ which provide $\mathrm{r}$ stationary linear combinations of $\beta^{!} \mathrm{X}_{\mathrm{t}-\mathrm{q}}$.

The linear likelihood ratio (LR) statistics for testing hypothesis $H_{0}=\Pi_{q}=\alpha \beta$ ! is a test that there are at most $r$ Co-integrating vectors;

$$
\lambda_{\max }=-T \ln \left(1-X_{r+1}\right)
$$

Versus an alternative,

$$
\lambda_{\text {trace }}=-T \sum_{i=r+1}^{K} \ln \left(1-\lambda_{i}\right)
$$

The linear restriction (LR) statistic for testing $r$ against $r+1$ co-integrating vectors is given by:

$$
-2 \ln (Q)=T \sum_{i=1}^{r} \ln \left(\frac{1-\lambda !}{1-\lambda_{i}}\right) .
$$

This determines the significant Eigen values and the corresponding number of eigenvector.

\begin{tabular}{|c|c|c|c|c|}
\hline & \multicolumn{2}{|c|}{ ADF TEST } & \multirow{2}{*}{\multicolumn{2}{|c|}{$\begin{array}{l}\text { Order of Integration } \\
\text { I(D)/Integration order }\end{array}$}} \\
\hline Variables & Levels & $\begin{array}{l}\text { First } \\
\text { Difference }\end{array}$ & & \\
\hline FDI/GDP(Y) & $\begin{array}{l}\mathbf{( - 1 . 0 9 9 7 7 8 )} \\
-4.296729 \\
-3.568379 \\
{[\mathbf{0 . 9 1 2 4}]} \\
\end{array}$ & $\begin{array}{l}\mathbf{( - 4 . 8 7 1 2 5 8 )} \\
-4.309824 \\
-3.574244^{*} \\
{[0.0027]} \\
\end{array}$ & 7 & $\mathrm{I}(1)$ \\
\hline MSIZE & $\begin{array}{l}\mathbf{( - 1 . 9 5 8 9 0 0 )} \\
-4.309824 \\
-3.574244 \\
{[\mathbf{0 . 5 9 8 4}]}\end{array}$ & $\begin{array}{l}\mathbf{( - 4 . 6 0 3 6 4 1 )} \\
-4.323979 \\
-3.580623^{*} \\
(\mathbf{0 . 0 0 5 3 )}\end{array}$ & 7 & $\mathrm{I}(1)$ \\
\hline REEX & $\begin{array}{l}\mathbf{( - 3 . 1 4 5 2 5 0 )} \\
-4.296729 \\
-3.568379 \\
{[\mathbf{0 . 1 1 4 6}]} \\
\end{array}$ & $\begin{array}{l}\mathbf{( - 6 . 8 5 0 8 6 8 )} \\
-4.309824 \\
-3.574244^{*} \\
{[\mathbf{0 . 0 0 0 0}]} \\
\end{array}$ & 7 & $\mathrm{I}(1)$ \\
\hline POL & $\begin{array}{l}\mathbf{( - 1 . 3 4 9 3 0 6 )} \\
-4.296729 \\
-3.568379 \\
{[\mathbf{0 . 8 5 5 2}]} \\
\end{array}$ & $\begin{array}{l}\mathbf{( - 5 . 9 1 1 8 6 2 )} \\
-4.309824 \\
-3.574244^{*} \\
{[\mathbf{0 . 0 0 0 2}]} \\
\end{array}$ & 7 & $\mathrm{I}(1)$ \\
\hline NAT & $\begin{array}{l}\mathbf{( - 2 . 9 6 4 9 9 7 )} \\
-4.296729 \\
-3.568379 \\
{[\mathbf{0 . 1 5 8 1}]}\end{array}$ & $\begin{array}{l}\mathbf{( - 4 . 6 0 0 6 8 5 )} \\
-4.339330 \\
-3.587527^{*} \\
{[\mathbf{0 . 0 0 5 5}]}\end{array}$ & 7 & $\mathrm{I}(1)$ \\
\hline INFRA & $\begin{array}{l}\mathbf{( - 3 . 8 4 2 0 2 0 )} \\
-4.416345 \\
-3.622033^{*} \\
{[0.0325]}\end{array}$ & & 7 & $\mathrm{I}(0)$ \\
\hline
\end{tabular}

\section{Presentation of Results, Analysis and Discussion}

\subsection{Unit Root Tests}

Table 1. Results of unit root tests

MacKinnon (1996) one-sided p-values [ ], *5\% significance. 
The results of unit root tests are presented in Table 1. The ADF-test statistics is in parenthesis as against that of critical values. All the analyses are based on critical values at 5 percent levels. Here, the null hypothesis which states that the variable is non-stationary is rejected, if the ADF-test statistics is greater than critical values at $5 \%$ levels of significance. The results indicate that only infrastructure (infra) is stationary at levels. All the other variables included in this study were non- stationary at levels. However after first differencing, all the other variables which were non-stationary at levels became stationary. This indicates that all the data series are integrated of the same order. The researchers used Eviews 7 econometric software package for the various tests.

\subsection{Co-integration Test Results}

Trend assumption: Linear deterministic trend

Series: FDI MSize NAT REEX INFRA POL

Lags interval (in first differences): 1 to 1

Table 2. Unrestricted co-integration rank test (Trace)

\begin{tabular}{ccccc}
\hline \hline $\begin{array}{c}\text { Hypothesized } \\
\text { No. of CE(s) }\end{array}$ & Eigenvalue & $\begin{array}{c}\text { Trace } \\
\text { Statistic }\end{array}$ & $\begin{array}{c}0.05 \\
\text { Critical Value }\end{array}$ & Prob.** \\
\hline \hline None ${ }^{*}$ & 0.891823 & 151.2558 & 95.75366 & 0.0000 \\
At most $1{ }^{*}$ & 0.796532 & 86.76034 & 69.81889 & 0.0012 \\
At most 2 & 0.536162 & 40.58514 & 47.85613 & 0.2022 \\
At most 3 & 0.369991 & 18.30675 & 29.79707 & 0.5435 \\
At most 4 & 0.154600 & 4.908122 & 15.49471 & 0.8185 \\
At most 5 & 0.001300 & 0.037714 & 3.841466 & 0.8460 \\
\hline \hline
\end{tabular}

Trace test indicates 2 Co-integrating eqn(s) at the 0.05 level

* denotes rejection of the hypothesis at the 0.05 level

**MacKinnon-Haug-Michelis (1999) p-values

Table 3. Unrestricted co-integration rank test (Maximum eigenvalue)

\begin{tabular}{ccccc}
\hline \hline $\begin{array}{c}\text { Hypothesized } \\
\text { No. of CE(s) }\end{array}$ & Eigenvalue & $\begin{array}{c}\text { Max-Eigen } \\
\text { Statistic }\end{array}$ & $\begin{array}{c}0.05 \\
\text { Critical Value }\end{array}$ & Prob.** \\
\hline \hline None * & 0.891823 & 64.49549 & 40.07757 & 0.0000 \\
At most 1 & 0.796532 & 46.17520 & 33.87687 & 0.0011 \\
At most 2 & 0.536162 & 22.27839 & 27.58434 & 0.2064 \\
At most 3 & 0.369991 & 13.39863 & 21.13162 & 0.4162 \\
At most 4 & 0.154600 & 4.870408 & 14.26460 & 0.7581 \\
At most 5 & 0.001300 & 0.037714 & 3.841466 & 0.8460 \\
\hline \hline
\end{tabular}

Max-eigenvalue test indicates 2 Co-integrating eqn(s) at the 0.05 level

* denotes rejection of the hypothesis at the 0.05 level

**MacKinnon-Haug-Michelis (1999) p-values

Tables 2 and 3 report the results of the co-integration test. Both tests results as shown above indicate the existence of co-integration among the data series. Both tests indicate at least one co-integration equations at $5 \%$ levels. Specifically, both the Trace test and the Rank test indicate the existence of 2 co-integrating equations at $5 \%$ level. Thus, the null hypothesis which indicates the non-existence of co-integration among the data series is rejected. The implications of these tests results are that; first, the selected variables share a common stochastic trend and will grow proportionally. That is to say, there exist a long run relationship among the variables and they move along together in the long run and short term deviations will be corrected towards equilibrium. Secondly, co-integration literally indicates causality in at least one direction. 


\subsection{Vector Error Correction Model (VECM) Results}

Dependent Variable: D(FDI)

Method: Least Squares

Included observations: 28 after adjustments

$\mathrm{D}(\mathrm{FDI})=\mathbf{C}(1) *($ FDI $(-1)+\mathbf{0 . 0 0 0 7 7 0 8 1 3 1 2 9 9 0 9 * G D P}(-1)-\mathbf{0 . 3 1 3 8 5 4 4 1 1 2 4 4}$

*NAT(-1) - 0.0037224716991*REEX(-1) - 1.31788635942*POL(-1) +

3.29435285726*INFRA(-1) + 4.66711336653) + C (2)*D(FDI(-1)) + C(3)

*D(FDI(-2)) + C(4)*D(GDP(-1)) + C(5)*D(GDP(-2)) + C(6)*D(NAT(-1))+

$\mathrm{C}(7) * \mathrm{D}(\mathrm{NAT}(-2))+\mathrm{C}(8) * \mathrm{D}(\operatorname{REEX}(-1))+\mathrm{C}(9) * \mathrm{D}(\operatorname{REEX}(-2))+\mathrm{C}(10)$

$* \mathrm{D}(\mathrm{POL}(-1))+\mathrm{C}(11) * \mathrm{D}(\mathrm{POL}(-2))+\mathrm{C}(12) * \mathrm{D}(\operatorname{INFRA}(-1))+\mathrm{C}(13)$

$* \mathrm{D}(\operatorname{INFRA}(-2))+\mathrm{C}(14)$

Table 4. VECM short-run estimates

\begin{tabular}{rrrrr}
\hline \hline & Coefficient & Std. Error & t-Statistic & Prob. \\
\hline \hline C(1) & -0.279254 & 0.121672 & -2.295136 & 0.0377 \\
C(2) & -0.079202 & 0.203144 & -0.389881 & 0.7025 \\
C(3) & -0.123654 & 0.174156 & -0.710019 & 0.4894 \\
C(5) & 0.028411 & 0.020429 & 1.390726 & 0.1860 \\
C(6) & 0.072027 & 0.037228 & 1.934768 & 0.0735 \\
C(7) & 0.072520 & 0.033434 & -2.169027 & 0.0478 \\
C(8) & 0.004157 & 0.023113 & -0.179869 & 0.8598 \\
C(9) & 0.000806 & 0.000448 & 1.800421 & 0.0934 \\
C(10) & 0.000282 & 0.000744 & 0.378666 & 0.7106 \\
C(11) & 0.662453 & 0.356665 & 1.857354 & 0.0844 \\
C(12) & -0.380759 & 0.414326 & -0.918984 & 0.3737 \\
C(13) & -4.200535 & 1.530129 & -2.745216 & 0.0158 \\
C(14) & -1.961364 & 1.739832 & -1.127330 & 0.2786 \\
\hline \hline R-squared & -0.616628 & 0.401718 & -1.534976 & 0.1471 \\
Adjusted R-squared & 0.719704 & Mean dependent var & & 0.273901 \\
S.E. of regression & 0.459428 & S.D. dependent var & & 1.061193 \\
Sum squared resid & 0.780227 & Akaike info criterion & & 2.648389 \\
Log likelihood & 8.522558 & Schwarz criterion & & 3.314491 \\
F-statistic & -23.07745 & Hannan-Quinn criter. & & 2.852023 \\
Prob(F-statistic) & 2.765163 & Durbin-Watson stat & & 2.031317 \\
\hline \hline
\end{tabular}

\subsection{Long-Run and Short- Run Relationships: Analysis and Discussions}

The results of the VECM are presented in the Table 4 above. The long-run relationship between the dependent variable and the independent variables are shown in the equation 3 above (see bold). The analysis under this model is based on one period lag values of the variables in the model. This is particularly important due to the annual nature of time series the data. From equation 3 above, it could be observed that there exist a long-run positive relationship between GDP and FDI. To be specific, a 10\% increase in GDP leads to a corresponding increase of approximately $0.001 \%$ in FDI inflows. This estimate is however insignificant. The short-run relationship between GDP and FDI is also positive but insignificant. That is, in the short-run, a 10\% increase in GDP will lead to a corresponding increase of 7\% in FDI inflows (see C4). This result is inconsistent with Vijayamur et al., (2010) and Asiedu (2006) who found positive and significant relation between market size and the level of inflows. The insignificant coefficient for market size might be due to the resource seeking motives of inflows into Ghana. It has been suggested that foreign investors operating in the extractive sector generally export their products and are therefore not particularly concerned with the size of the host country's market (Ezeoha \& Cattaneo, 2011). 
The results as presented in the equation 3 above also indicate a negative long-run relationship between natural resource endowment and FDI inflows. Specifically, a 10\% increase in natural resource leads to a decrease of approximately $3 \%$ in FDI inflows in the long run. In the short run however, natural resource endowment contributes positively toward FDI inflows (see C6). Both estimates are statistically significant at 5\% levels. The result of the short-run estimate is consistent with UNCTAD (2005) which found that as high as $80 \%$ of FDI inflow to Africa is concentrated in the extractive sector. Similarly previous studies by Ezeoha and Cattaneo (2011) and Asiedu (2002) have shown that natural resource endowments play a leading role in attracting inflow to countries in Africa. The long-run negative relationship between FDI and natural resource endowment may appear to be surprising considering the position in theory. However, the result is practically not out of place. Earlier research by Poelhekke and van der Ploeg (2010) provides some explanation as to why in the long-run natural resource endowment might negatively impact FDI inflows in a country. According to theses researchers, the ruling elite of a country may forms a coalition with foreign resource companies to appropriate resource rents at the expense of the people in an environment where information on resource exploration/exploitation and returns to companies and the government are not very transparent. This view had earlier been shared by Durnev and Guriev, (2007) who opine that predatory governments may induce corporations to become less transparent and less efficient, especially in industries whose profits are highly correlated with oil prices. Thus, is a country where information on the resource rents and exploration/exploitation of natural resources are held by government officials as corporate secrete and deny the populace access to such relevant information, as has been the case in Ghana, the abundance of these natural resources could in the long-run deter FDI inflows.

Also evidenced in the results shown in equation3 is the fact that there exist a long-run negative and significant relationship between FDI inflows and Real Effective Exchange rate. In the long-run a 10\% increase in the value of the cedi leads to a decrease of $0.03 \%$ in FDI inflows to Ghana. In the short-run however, a $10 \%$ strengthening of the value of the Cedi leads to a corresponding increase of $0.008 \%$ in FDI inflows (see C8). Thus, there exist a positive short-run relationship between FDI and exchange rate but this estimate is insignificant in the short-term. The implication of the short run result is that the value of the cedi against other major currencies does not affect foreign direct investors' decision to invest in Ghana. This finding is not surprising giving that most of FDI inflow in Ghana target the extractive industries. Asiedu (2006) and Ezeoha and Cattaneo (2011) all argue to the effect that resource-seeking FDI's are less concerned with host country macroeconomic factors at least in the short term. The long term implication of this result could not be ignored. The negative and significant relationship indicates that in the long-run a depreciation of the cedi against the major currencies improves FDI inflows in Ghana. Possible reasons to this result could be due to the fact that an undervalued exchange rate of host country creates more profitable opportunities for foreign investment, since the real value of foreign investors' capital assets goes up (Kohlhagen, 1977; Logue \& Willet, 1977; Stevens, 1993). In other words, a depreciation of the host country's currency means that the foreign currency becomes more valuable, so the foreign investors can spend less on the same project in host market than the expense required before, when we assume the price staying still. It is also the reason for exports growth when the host currency gets worthless. This might partly explain the recent increase in FDI inflows Ghana. The value of the cedi has been depreciating consistently in recent years and it is during this same period that the FDI inflows in Ghana have been increasing.

Furthermore, the results of the VECM as presented above indicate a negative and very significant long term relationship between political instability and FDI inflows in Ghana. It could be observed that in the long-run, a 10\% increase in political instability in the country would lead to a decline of $\mathbf{1 3 . 2 \%}$ in FDI inflows. The result is similar to findings by Azzumonti and Sarte (2007) and Asiedu (2006). Political uncertainties deter FDI because of creeping fears of expropriation and the image of Africa as continent prone to conflict and internal strife. The political history of Ghana may have also played a significant role in making this variable strong and significant. Since independence the country's history has been dotted with numerous government overthrows and expropriations following coup d'état and as a consequence foreign investors have become more responsive to any semblance of political uncertainties. Conversely, political certainty afforded by the current democratic dispensation should serve as a driver of FDI. In effect deepening our democratic institutions will immensely affect the level of FDI by reducing perceived political risk. The short term relationship between political instability and FDI inflows is however insignificant.

Finally, a positive long-run and significant relationship is established between FDI inflows and Infrastructure. To be specific, a $10 \%$ increase in infrastructure would lead to a corresponding increase of $\mathbf{3 0 . 2 \%}$ in FDI in the long-run. The short-run estimate between infrastructure and FDI is however negative and significant (see C12). That is in the short run, a $10 \%$ increase in infrastructure correspondingly leads to decrease of $40.2 \%$ in FDI inflows. This result is inconsistent with findings of Vijayamur et al., (2010), and Ezeoha and Cattaneo (2011). These authors found 
infrastructure to have positive impacted on FDI which is hardly surprising. Interestingly however, Asiedu (2006) establish a positive but insignificant relationship on countries in Africa. The result of this paper clearly underscores the fact that current state of infrastructure in the country might be deterring FDI inflows in Ghana and therefore contributing negatively. Thus, there still exist huge potential for Ghana to attractive more FDI if we improve significantly on the infrastructural state of the economy.

\subsection{Model Efficiency Diagnoses}

To check the robustness of the estimated co-efficient of the independent variables, we perform various tests to check the efficiency of the VECM model. We first look at the test statistics of the VECM model. The R square of the model is 0.719704 which indicates that the independent variables included in the model explain approximately $72 \%$ of the observed variations in the FDI inflows in Ghana. This is very significant for a time series data. The F-statistic is 2.765163 with a probability of 0.034853 . Thus, the overall impact of the independent variables on FDI is very significant. The overall acceptance of the VECM model is dependent on the value of $\mathrm{C} 1$ and its significance. For the model to be accepted, the value of $\mathrm{C} 1$ should be negative and statistically significant at $5 \%$ levels. From table 3 , the value of $\mathrm{C} 1$ is -0.279254 and its $\mathrm{P}$-value is 0.0377 , at $5 \%$ level of significance. Thus, the model is accepted. The negative and significant value of $\mathrm{C} 1$ also confirms the existence of long-run relationship among the data series. The value of $\mathrm{C} 1$ represents the error correction term and it indicates the rate at which the disequilibrium between the long-run and the short-run estimates are corrected for. The results in table 4 show that on annual basis; approximately $28 \%$ of the disequilibrium between the long-run and short-run estimates are corrected for and brought back to equilibrium.

We checked for Serial Correlation, Normality and Heteroskedasticity by performing various residual diagnostic tests. To test for the presence of serial correlation or autocorrelation among the data series, we employed the Breusch-Godfrey Serial Correlation LM Test. Here, we run the null hypothesis $\left(\mathrm{H}_{0}\right)$ which states that there is no serial correlation in the residuals against an alternative $\left(\mathrm{H}_{1}\right)$ that there is serial correlation in the residuals. When the p-value of the observed $\mathrm{R}$ square of the test is more than $5 \%$ (i.e. P-value $>5 \%$ ) we cannot reject $\mathrm{H}_{0}$ and thus conclude that there is no serial correlation in the residuals.

Table 5. Breusch-Godfrey serial correlation LM test results

\begin{tabular}{llll}
\hline \hline F-statistic & 0.761387 & Prob. F(2,12) & 0.4883 \\
Obs*R-squared & $\mathbf{3 . 1 5 3 0 2 8}$ & Prob. Chi-Square(2) & $\mathbf{0 . 2 0 6 7}$ \\
\hline \hline
\end{tabular}

From the results as shown in the Table4 above, the observed R square of the residuals is 3.153028 with a probability Chi-Square value of 0.2067 , which is more than 5\% (i.e. 20.6\%). It can therefore be concluded that the data series in the model are free from serial correlation, which is desirable.

Further, we performed the Normality Test: Jarque-Bera, to check whether the residuals of the estimates are normally distributed or not. Here we tested the Null hypothesis $\left(\mathrm{H}_{0}\right)$ which states that the residuals of the estimates are normally distributed against the alternative $\left(\mathrm{H}_{1}\right)$ that the residuals are not normally distributed. We accept the $\left(\mathrm{H}_{0}\right)$ when the P-value of the Jarque-Bera statistic is more than 5\% (i.e. P-value $>5 \%$ )

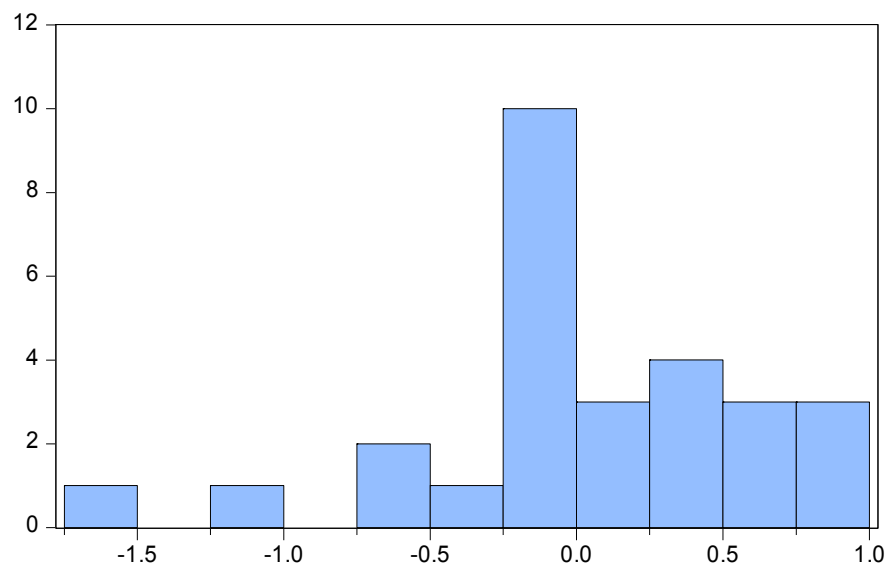

Series: Residuals Sample 19832010 Observations 28

Mean $\quad 4.56 \mathrm{e}-17$

Median $\quad-0.050539$

Maximum $\quad 0.819146$

Minimum $\quad-1.602883$

Std. Dev. $\quad 0.561828$

Skewness $\quad-0.847026$

Kurtosis $\quad 3.953071$

Jarque-Bera $\quad 4.407845$

Probability $\quad 0.110369$

Figure 1. Normality test: Jarque-Bera 
From the histogram above, it is observed that the Jarque-Bera statistic is 4.4078 with a probability value (P-value) of 0.1104 (e.i. 11\%) which is more than 5\%. Thus, we accept the Null $\left(\mathrm{H}_{0}\right)$ that the residuals of the estimates are normally distributed and reject the alternative $\left(\mathrm{H}_{1}\right)$. We therefore draw the conclusion that the data series included in the VECM model are normally distributed.

Finally, we tested for the presence of heteroskedasticity in the data series. With this test, we used the Breusch-Pagan-Godfrey statistic. Here we run the Null hypothesis $\left(\mathrm{H}_{0}\right)$ which states that the residuals of the estimates are not heteroskedastic against the alternative $\left(\mathrm{H}_{1}\right)$ that the residuals are heteroskedastic. We accept the $\left(\mathrm{H}_{0}\right)$ when the P-value of observed R-square in the Breusch-Pagan-Godfrey statistic is more than 5\% (i.e. P-value $>5 \%$ ).

Table 6. Heteroskedasticity test: Breusch-Pagan-Godfrey

\begin{tabular}{llll}
\hline \hline F-statistic & 0.597612 & Prob. F(18,9) & 0.8315 \\
Obs*R-squared & 15.24504 & Prob. Chi-Square(18) & $\mathbf{0 . 6 4 5 1}$ \\
Scaled explained SS & 5.627459 & Prob. Chi-Square(18) & 0.9975 \\
\hline \hline
\end{tabular}

The results as shown in the Table 6 above, indicates the acceptance of the Null $\left(\mathrm{H}_{0}\right)$ that the residuals are free from heteroskedastic effects. The observed R square of the residuals is 15.24504 with a probability Chi-Square value of 0.6451, which is more than 5\% (i.e. 64.5\%). It can therefore be concluded that the data series in the model are homoskedastic, which is desirable in a time series data. In summary, all the efficiency diagnostic tests conducted on the residuals point to the fact that the data series are free from serial correlation, the data is normally distributed and also homoskedastic.

\section{Conclusion}

This has paper reveal that FDI inflows to Ghana are significantly impacted by natural resource endowments, in the short-run. It has also underscored the fact that Ghana cannot continuously rely on its natural resources as a factor that will bring in more FDI inflows in the long-run. Infrastructural development and political stability appears to hold the key to long-term inflows of FDI in Ghana. The findings have several policy implications. For example, this paper has revealed that political instability greatly deter FDI inflows. Thus, consolidating the democratic gains of Ghana can offer economic gains by serving as a driver of FDI. The state of infrastructural development in Ghana is seen to be below the threshold necessary to attract more FDI. However, the positive long-run relationship indicates that Ghana stands to gain more on FDI inflows with improvement in its current state of infrastructural development. To attract efficiency seeking and market seeking FDI that hugely depend on infrastructure the country need to upgrade the current levels of infrastructure. Contrary to the widely held opinion, market size is found to be insignificant. Whiles the depreciation of the Ghana cedi will serve as a long-term incentive for FDI inflows into Ghana. This particular situation might be why china for long has strategically devalued the Yuan as trade competitive tool and to also attract FDI into china. Should Ghana follow suit by first managing its exchange rate? The academic debate must continue. The insignificant nature of the size of the economy in attracting FDI should be a source of concern for Ghana. This macroeconomic factor is associated with market seeking FDI which is a more desirable form of FDI because it has huge economic impact on host economy. To attract this market seeking FDI, it is suggested that Ghana should fast track its integration into sub regional market (West Africa monetary zone). This might serve to increase the population size and income levels in order to achieve a market size large enough to attract market seeking FDI.

\section{References}

Asiedu, E. (2002). On the Determinants of Foreign Direct Investment to developing Countries: Is Africa different? World Development, 30(1), 107-199.

Asiedu, E. (2005). Foreign Direct Investment in Africa: The Role of Natural Resources, Market Size, Government Policy, Institutions and Political Instability. UNU-WIDER.

Azzimonti, M., \& Sarte, G. (2007). Barriers to Foreign Direct Investment Under Political Instability. Economic Quarterly, 93(3), 287-315.

Chakrabraoti, A. (2001). The Determinants of Foreign Direct Investment: Sensitivity Analyses of Cross-Country Regressions. KYLOS, 54.

Dickey D., \& Fuller, W. (1979). Distribution of the estimators for Autoregressive time series with unit root. Journal of American Statistical Association, Economic Review, 84(5), 1310-1329. 
Dupasquier, C., \& Osakwe P. N. (2005). Foreign Direct Investment in Africa: Performance, Challenges and Responsibilities. United Nations Economic commission for Africa.

Ezeoha. E. A., \& Cattaneo, N. (2011). FDI flows to Sub-Saharan Africa; impact of finance institution and natural resource endowment. Paper Submission for the CSAE Conference: Economic Development in Africa.

Frimpong, J. M., \& Marbuah, G. (2010). "The Determinants of Private Sector Investment in Ghana": An ARDL Approach. European Journal of Social Sciences, 15(2).

Johansen, S., \& Juselius, K. (1990). Maximum Likelihood Estimation and Inference on Co-integration with Applications to the Demand for Money. Oxford Bulletin of Economics and Statistics, 52, 169-210. http://dx.doi.org/10.1111/j.1468-0084.1990.mp52002003.x

Kobrin S.J. (2005). The determinants of Liberalization of FDI policy in developing country a cross sectional analysis 1992 - 2001. Transnational Corporation, 14(1).

Logue, D.E., \& Willet, T.D. (1977). The effects of exchange rate adjustments on international investment. In P.B. Clark, D.E. Logue and R. Sweeney (Eds.), The Effects of Exchange Rate Adjustments (pp. 137-150). Washington DC: US Government Printing Office.

Obwona M., \& Egesa, K. (2004). FDI Flows to Sub - Saharan Africa Uganda Country Case study. Economic Policy Research Centre.

Ploeg, F. van der, \& Poelhekke S. (2009). Volatility and the natural resource curse. Oxford Economic Papers, 61(4), 727-760. http://dx.doi.org/10.1093/oep/gpp027

Stevens, G.V.G. (1993). Exchange rates and foreign direct investment: a note. International Finance Discussion Papers, April, No. 444, Washington DC: Board of Governors of the Federal Reserve System.

UNCTAD. (2005). The Competitiveness Challenge: Transnational Corporations and Industrial Restructuring in Developing Countries, Geneva: UNCTAD.

UNCTAD. (2008). FDI in Africa hits record, and continent has highest returns on investment of all developing regions.

Vijayakuma, N., Soidharan, P., \& Sekhara Rao K.C. (2010). "Determinants of FDI in BRICS countries": A panel analysis. International Journal of Business, 5(3), Working Paper 7810, National Bureau of Economic Research, Cambridge.

World Bank (2009). Economy-Wide Impact of Oil Discovery in Ghana. Report No. 47321-GH.

World Bank. (2010). World Development Indicators CD-ROM, for Ghana. Washington D.C.: World Bank.

World Investment report. (2008). Transnational Corporations and the Infrastructure. 